YEARBOOK

of ANTITRUST

and REGULATORY

STUDIES

www.yars.wz.uw.edu.pl
Peer-reviewed scientific periodical, focusing on legal and economic issues of antitrust and regulation. Creative Commons Attribution-No Derivative Works 3.0 Poland License.

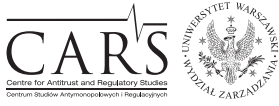

Centre for Antitrust and Regulatory Studies, University of Warsaw, Faculty of Management www.cars.wZ.uw.edu.pl

\title{
The Implementation of the ECN+ Directive in Hungary and Lessons Beyond
}

\author{
by
}

Katalin J. Cseres*

\section{CONTENTS}

I. Introduction

II. From Regulation 1/2003 to Directive 2019/1

1. Multi-level governance under Regulation 1/2003

2. 'Guided' convergence

III. Implementation of the ECN+ Directive in Hungary

1. Development of administrative procedures in competition law cases in Hungary

2. Changes necessary for the implementation of the Directive

2.1. Commitments

2.2. Fines

2.3. Leniency

IV. Institutional issues: independence and accountability

1. Relevance of institutions

2. Independence in EU law

3. Independence of the GVH

4. Accountability of the GVH

5. Judicial accountability

V. Conclusions

\section{Abstract}

In order to facilitate national competition authorities (NCAs) in their application of EU competition rules, the EU legislator adopted Directive 2019/1/EU. The Directive's aim is to empower the competition authorities of the Member States

* Associate Professor of Law, Amsterdam Centre for European Law and Governance, Amsterdam Center of Law \& Economics, University of Amsterdam; email: k.j.cseres@uva.nl. Article received: 15 August 2019; accepted: 19 November 2019. 
to be more effective enforcers of competition law and to ensure the proper functioning of the internal market. The so-called ECN+ Directive introduces minimum harmonisation rules allowing competition authorities to have common investigative, decision-making (notably fining decisions) and enforcement powers. The Directive, furthermore, sets minimum safeguards for the NCAs' independence, accountability and resources as well as harmonizes leniency programmes including the coordination of national leniency programmes with each other and with that of the European Commission.

This paper critically analyzes the legal and policy developments that paved the way for the adoption of this Directive. Moreover, it examines the changes the implementation of the Directive is likely to generate in current Hungarian law and policy of competition protection. The focus of the paper's assessment is on the institutional aspects of the Directive and the enforcement of Articles 101 and 102 TFEU, in particular the mechanisms for ensuring independence and accountability of the NCAs. Through the assessment of the Hungarian implementation, the paper aims to shed light on a broader context of the Directive and the enforcement of EU competition law in EU Member States. The paper shows that the implementation of the Directive may fail to translate into (more) effective enforcement without an effective institutional capacity on the side of the NCAs, and in the broader legal and constitutional context of competition law and its multilevel enforcement.

\section{Résumé}

Pour faciliter l'application des règles de concurrence de l'UE par les autorités nationales de concurrence, le législateur européen a adopté la directive 2019/1/UE. Lobjectif de la directive est de permettre aux autorités de concurrence des États membres d'être plus efficaces dans l'application du droit de la concurrence et d'assurer le bon fonctionnement du marché intérieur. La directive dite «ECN+» définit des règles minimales d'harmonisation permettant aux autorités de concurrence de disposer de pouvoirs communs d'enquête, de décision (notamment en matière d'amendes) et d'exécution. En outre, la directive fixe des garanties minimales pour l'indépendance, la responsabilité et les ressources des ANC, harmonise les programmes de clémence, y compris la coordination des programmes nationaux de clémence entre eux et entre ces programmes et ceux de la Commission européenne.

Le présent article analyse de manière critique les développements juridiques et politiques qui ont ouvert la voie à l'adoption de la directive. En outre, il examine les changements que la mise en œuvre de la directive est susceptible de générer dans la législation et la politique hongroises actuelles en matière de protection de la concurrence. Au centre de l'évaluation du présent document figurent les aspects institutionnels de la directive et l'application des articles 101 et 102 du TFUE, en particulier les mécanismes garantissant l'indépendance et la responsabilité des ANC. Grâce à l'évaluation de la transposition hongroise, le présent article vise à clarifier le contexte plus large de la directive et de l'application du droit 
communautaire de la concurrence dans les États membres de l'UE. Larticle montre que la mise en œuvre de la directive pourrait ne pas se traduire par une application (plus) efficace sans une capacité institutionnelle effective de la part des ANC et dans le contexte juridique et constitutionnel plus large du droit de la concurrence et son application à plusieurs niveaux.

Key words: EU Competition law, Institutional design, Competition Law procedures, Hungary, Decentralization.

JEL: K10, K21, D02

\section{Introduction}

In order to facilitate national competition authorities (hereinafter: NCAs) in their application of EU competition rules, the EU legislator adopted Directive 2019/1/EU. The Directive's aim is to empower the competition authorities of the Member States to be more effective enforcers of competition law and to ensure the proper functioning of the internal market. ${ }^{1}$ The so-called ECN+ Directive introduces minimum harmonisation rules allowing competition authorities to have common investigative, decision-making (notably fining decisions) and enforcement powers. The Directive, furthermore, sets minimum safeguards for NCAs' independence, accountability and resources, harmonizes leniency programmes including the coordination of national leniency programmes with each other and with that of the European Commission. The Directive also addresses mutual assistance among NCAs and the role of NCAs before national courts. The Directive seeks to strengthen the cooperation between national competition authorities and the Commission within the framework of the European Competition Network (hereinafter: ECN). The Directive envisages giving NCAs enforcement powers similar to those enjoyed by the Commission.

This paper will, first, critically analyze the legal and policy developments that paved the way for the adoption of this Directive. Second, it will examine the changes the implementation of the Directive is likely to generate in current Hungarian law and policy of competition protection. The focus of the paper's assessment is on the institutional aspects of the Directive and the enforcement of Articles 101 and 102 TFEU, in particular the mechanisms for

\footnotetext{
1 Directive (EU) 2019/1 of the European Parliament and of the Council of 11 December 2018 to empower the competition authorities of the Member States to be more effective enforcers and to ensure the proper functioning of the internal market, OJ L 11, 14.01.2019, p. $3-33$.
} 
ensuring independence and accountability of NCAs. Through the assessment of the Hungarian implementation, the paper aims to shed light on a broader context of the Directive and the enforcement of EU competition law in the EU Member States. The paper shows that the implementation of the Directive may fail to translate into (more) effective enforcement without effective institutional capacity on the side of the NCAs and in the broader legal and constitutional context of competition law and its multilevel enforcement.

The paper is structured into five sections. The first section analyzes the way enforcement of EU competition law has been shaped by Regulation 1/2003, and which challenges the multi-level system posed to enforcement, and how the system developed and eventually led to the adoption of the Directive. The second section critically analyzes the way convergence of procedural and institutional issues among the Member States has taken place before the adoption of the Directive, and it shows that the Commission played a dominant role in this process. Section three turns to the developments of procedures and enforcement of competition law in Hungary and the possible challenges and necessary changes to implement the Directive in Hungary. Section four analyzes the way provisions on independence and accountability of the Directive may fall short of achieving a really effective enforcement of competition law in the Member States. Hungary's example shows that effective de facto independence of NCAs is key to enforcement, and that active mechanisms of political and judicial accountability need to be present in a legal and political system in order to guarantee effective (competition) law enforcement. The paper closes with conclusions.

\section{From Regulation 1/2003 to Directive 2019/1}

The fundamental procedural rules for the application of Articles 101 and 102 TFEU have been laid down in Regulation 17/62. After remaining unchanged for forty years, in 2004 Regulation 1/2003 introduced vital changes to the enforcement of Articles 101 and 102 TFEU $^{2}$ with the aim to ensure effective enforcement on the one hand, and to simplify their administration to the greatest possible extent on the other. Regulation 1/2003 delegated enforcement powers to NCAs and national courts to relieve the Commission of its increasing administrative burden and make the enforcement of EU rules more effective. Regulation 1/2003 created a system of parallel competences between the Commission and NCAs and national courts and obliged the

2 Council Regulation (EC) 1/2003 of 16 December 2002 on the implementation of the rules on competition laud down in Articles 81 and 82 of the Treaty [2003] OJ L1/1. 
national enforcers to apply EU and national competition laws simultaneously. This transformation of EU competition law enforcement (see: Cseres, 2015) resulted in a multilevel governance system, where a mix of substantive EU provisions and national procedural laws and institutional designs are applied and enforcement is shared by the Commission and 28 national competition authorities. Accordingly, decentralized enforcement of EU competition law became subject to problems of multilevel governance similar to other fields of EU law.

When NCAs apply Articles 101 and 102 TFEU, they make use of their national procedural rules and impose remedies and sanctions that are available in their respective legal systems. Thus, the enforcement of EU competition rules has come to rely on the effective administrative enforcement of EU competition rules through national administrative procedures. This system created an enforcement gap between substantive and procedural rules and raised the problem of accountability for acts which are the result of this mixed enforcement system (Cengiz, 2009; Cseres, Outhuisje, 2017, pp. 82-114).

\section{Multi-level governance under Regulation 1/2003}

This multilevel enforcement system challenged the uniform and consistent application of EU competition law and created uncertainty for national enforcers how to apply and not to apply Treaty provisions. In order to remedy this problem, various legal provisions were laid down in Regulation 1/2003 and cooperation mechanisms between the Commission and the NCAs were introduced in the framework of the European Competition Network. ${ }^{3}$ While these mechanisms accelerated a remarkable Europeanization ${ }^{4}$ of competition rules, ${ }^{5}$ much of the effectiveness of the decentralized enforcement now depends on the success of the coordination mechanisms between centrifugal pulls from the Member States towards their national legal systems and centripetal pushes from the Commission to safeguard uniform and consistent application. ${ }^{6}$

\footnotetext{
${ }^{3}$ Commission Notice on cooperation within the Network of Competition Authorities [2004] OJ C101/43.

${ }^{4}$ Europeanisation is understood as 'the reorientation or reshaping of politics in the domestic arena in ways that reflect policies, practices or preferences advanced through the EU system of governance' (Bache, Jordan, 2006; Cseres, 2014, 31-66).

${ }^{5}$ For example, when candidate countries join the EU and its competition law regime, external incentives and conditionality end their function as governance modes and the mechanisms within the ECN became crucial.

${ }^{6}$ While the legitimacy of shared enforcement depends on its compliance with the Rule of Law values. The main factors of effective competition law enforcement lie in effective administrative organisation, clearly worded national law provisions and the extent to which
} 
In the first place, Regulation 1/2003 modernized and implemented the procedural rules that apply to the enforcement of the Commission in cases of Articles 101 and 102 TFEU. It is the legal basis of the Commission's investigation powers. However, it did not formally intervene with the procedures of NCAs over and above Article 5 and 35 of Regulation 1/2003 and the rules applicable to cooperation mechanisms. Regulation 1/2003 contains some basic rules on the powers of the NCAs, but left national procedures and institutional designs unaddressed. Article 5 lists the powers of NCAs when they apply Articles 101 and 102 TFEU and what type of decisions the NCAs can take in such cases. But Article 5 is a very basic provision and did not formally regulate or harmonize the procedural rules to be followed by the NCAs or the ECN. 7 This means that the NCAs apply the same substantive EU rules, but they do so in different procedural frameworks and may impose different sanctions. These procedural differences had been addressed to some extent in Articles 11 and 12 of Regulation 1/2003 through the cooperation of the NCAs within the ECN. The procedures and sanctions for the application of EU competition rules in the Member States were thus not harmonized by Regulation 1/2003, and they are only subject to general principles of EU law, in particular, the principles of effectiveness and equivalence, as well as the observance of the fundamental rights enshrined in the Charter of Fundamental Rights of the European Union and the European Convention on Human Rights where applicable.

With regard to the institutional setup of NCAs, under Article 35 of Regulation 1/2003, each Member State had a clear obligation to designate a competition authority responsible for the application of Articles 101 and 102 TFEU before 1 May 20048. The chosen authorities could be administrative or judicial in nature. The only requirement was that they had to be designated in order to guarantee that the provisions of Regulation 1/2003 are effectively complied with. ${ }^{9}$ Beyond Article 35 of Regulation 1/2003, neither

European rules are successfully transposed into the existing institutional and regulatory traditions of the Member States (Treib, 2006; Knill, Lenschow, 1998).

7 European Commission, Commission Staff Working Paper accompanying the Report on Regulation 1/2003, SEC (2009) 574 final, para 200; Commission Staff Working Paper, Enhancing competition enforcement by the Member States' competition authorities: institutional and procedural issues, COM (2014)453, para 43.

8 Article 35(1) of Regulation 1/2003: 'The Member States shall designate the competition authority or authorities responsible for the application of Articles 81 and 82 of the Treaty in such a way that the provisions of this regulation are effectively complied with. The measures necessary to empower those authorities to apply those Articles shall be taken before 1 May 2004. The authorities designated may include courts.'

9 Point 2 of the Notice on cooperation within the NCA provides that 'Under general principles of Community law, Member States are under an obligation to set up a sanctioning system providing for sanctions which are effective, proportionate and dissuasive for infringements of EC law.' See also judgment of the Court of Justice of the European Union of 13 September 
further requirements nor additional formal rules have been formulated on the powers and procedures to be followed by the NCAs. ${ }^{10}$ The diversity of the NCAs' institutional design is largely determined by country-specific traditions (The Reports of the ECN's Working Group on cooperation issues and due process provide an overview of the different systems and procedures for antitrust investigations within the ECN. See: ECN Working Group Cooperation Issues and Due Process, 2012, p. 6-7; Cseres, 2013).

Given this diverse procedural and institutional landscape, it has been questioned whether the decentralized enforcement system where NCAs operate under different national procedural rules and impose a variety of sanctions and remedies, could jeopardize effective EU law enforcement (Cseres, 2017 B, pp. 182-199).

Cases such as, VEBIC, ${ }^{11}$ Tele2 Polska ${ }^{12}$ Orange $^{13}$ and Schenker ${ }^{14}$ clearly signaled that there are fundamental legal puzzles that arise when NCAs apply Articles 101 and 102 TFEU under domestic procedural rules. ${ }^{15}$

As Advocate General Kokott argued in T-Mobile Netherlands and Others: '[i]n those circumstances, it is of fundamental importance that the uniform

2005, Case C-176/03, Commission of the European Communities v Council of the European Union, ECR I-7879, paras 46-55.

10 Albeit their competences were very roughly set out in Articles 5 and 6 of Regulation 1/2003. Although national procedural rules had to provide for the admission of the Commission as amicus curiae in national procedures, NCAs will have to be empowered to conduct examinations in accordance with Regulation 1/2003, and Member States will have to report to the Commission. The Commission retains broad supervisory powers that allows it to intervene in proceedings before national authorities and which in fact enables it to act as 'primus inter pares'. See Article 11(6).

11 See Case C-439/08, Vlaamse federatie van verenigingen van Brood-en Banketbakkers, Ijsbereiders en Chocoladebewerkers (VEBIC) VZW, para 56: Article 35(1) requests that the NCAs are designated in such a way that the provisions of Regulation 1/2003 are effectively complied with. Agencies must ensure that the Treaty competition provisions are 'applied effectively in the general interest' See Van Cleynenbreugel, 2012, p. 285-312).

12 Case C-375/09, Prezes Urzędu Ochrony Konkurencji i Konsumentów v Tele2 Polska sp. z o.o., now Netia SA w Warszawie. CJEU, C-360/09, Pfleiderer AG v Bundeskartellamt; CJEU, C-681/11, Schenker \& co; Case C-557/12, Kone AG, Otis GmbH, Schindler Aufzüge und Fahrteppen $\mathrm{GmbH}$ et al v. OBB- Infrastruktur AG [June 5th, 2014, not yet published], para. 32.

13 T-402/13 Orange v Commission [2014]. In this case the General Court confirmed and further clarified the powers of the Commission to investigate practices that had been investigated earlier by a NCA. The General Court confirmed that the Commission's unannounced inspection on Orange's premises in relation to an alleged infringement of Article 102 TFEU in the market for internet connectivity services did not violate the principle of ne bis in idem paras 30-31.

14 See also Case C-681/11, Schenker\&co, para 46.

15 Opinion of Advocate General Kokott delivered on 19 February 2009 in Case C-8/08 (2009) ECR I-4529, p. 85. See judgment of the Court of Justice of 4 June 2009, Case C-8/08, T-Mobile Netherlands, ECR I-4529, paras 85 and 86; Petit, 2014. 
application of competition rules in the [European Union] be maintained. Not only the fundamental objective of equal conditions of competition for undertakings on the single market but also the concern for uniform protection of consumer interests in the entire [European Union] would be undermined if in the enforcement of the competition rules of Articles [101 and 102 TFEU] significant disparities occurred between the [NCAs] and courts of the Member States. For that reason, the objective of a uniform application of Articles [101 and 102 TFEU] is a central theme which runs throughout Regulation No 1/2003.'

Accordingly, it has been argued that consistent policy enforcement requires a certain degree of harmonization of procedures, resources and independence of the NCAs (Cengiz, 2009; Gauer, 2001, pp. 187-201; 2000, pp. 208-210).

The decentralized enforcement system of Articles 101 and 102 TFEU introduced by Regulation 1/2003 has often been characterized as a success and an effective way to enforce EU law. The decentralized enforcement system has been praised for effectively easing the Commission's workload by delegating enforcement powers to NCAs, national courts, and introducing a fundamental role for networked governance. Decentralized enforcement appears to work smoothly, and it has increased the Europeanization of competition rules across the Member States, while also developing a shared sense of competition policy and culture among the Member States.

However, there has also been serious criticism questioning the success of this enforcement model (Monti, 2014 A; Monti, 2014 B; Cseres, 2015, pp. 319-339). In fact, the Commission has also acknowledged that NCAs encounter difficulties in carrying out their work. Accordingly, late in 2015 the Commission started a public consultation on how to empower NCAs to be more effective enforcers. ${ }^{16}$

The next section will analyse how the Commission and the NCAs tried to deal with these difficulties and the way convergence among national procedural and institutional frameworks has developed until the legislative process of the Directive started.

\section{2. 'Guided' convergence}

Regulation 1/2003 reconciled the requirements of substantive coherence with the existing procedural diversity amongst NCAs. ${ }^{17}$ Article 3(2) of Regu-

16 European Commission, 'Empowering the national competition authorities to be more effective enforcers' http://ec.europa.eu/competition/consultations/2015_effective_enforcers/ index_en.html.

17 Commission Staff Working Paper accompanying the Report on the functioning of Regulation 1/2003 SEC(2009) 574 final, 29 April 2009, para 200. 
lation 1/2003 introduced a strict supremacy standard and has reinforced the process of convergence of substantive competition rules among Member States that started in the late 1980s. ${ }^{18}$ Most Member States also began to harmonize certain rules of their procedures towards Regulation 1/2003 and the accompanying soft-law instruments, most notably the Leniency Notice (Cseres, 2015, p. 319-339). Hungary has been one of the most active Member States in this respect as will be shown below. This convergence took place through implementing similar procedural rules as those of the Commission's. The underlying reason for these legal transplants ${ }^{19}$ could have been that once these rules and enforcement methods work effectively and efficiently in the hands of the Commission, they will prove successful in the hands of the NCAs as well.

Convergence has taken various forms from voluntary convergence by Member States to procedural convergence in the context of agreements on financial support from the EU with the Programme Countries, bilateral contacts and multilateral work within the ECN as well as reforms that have been stimulated by recommendations in the framework of the European Semester. ${ }^{20}$

Convergence has mostly been stimulated by the Commission. Consequently, it was the Commission who examined existing procedural divergences across the Member States and announced its intention to further harmonize national rules on procedures already in $2009 .{ }^{21}$ It was first after the five year

18 Competition law and policy gained importance and the ineffective abuse systems, which in certain jurisdictions included criminal law enforcement, was abandoned. Waarden and Drahos found that this convergence was due to a subtle top-down pressure from the Commission and the European courts combined with the emergence of strong epistemic community of competition lawyer (see: van Waarden, Drahos, 2002, p. 928). The new competition laws followed a prohibition system and enforcement was trusted to an administrative body with judicial like decision-making. Enforcement became primarily administrative law based, with administrative law sanctions. These new competition regimes worked more effectively than their predecessors and indeed their main achievement was to gain social and political support for the enforcement of competition law. See: Gerber, 1998, p. 402-403.

19 Convergence between different legal rules towards an efficient model may take place as a result of a legal transplant or as an outcome of a competitive process between different legal formants. In the first case, legal transplants are implemented because they proved to be efficient in other legal systems. In the second case, convergence towards efficiency is the result of the interaction between different legal formants. So, while legal transplants are governed by hierarchy, the second scenario is governed by competition among legal formants. See: Mattei, Antoniolli, Rossato, 2000, p. 508-511.

20 Commission Staff Working Paper, Enhancing competition enforcement by the Member States' competition authorities: institutional and procedural issues, COM (2014)453 paras $48-50$.

21 Commission Staff Working Paper, para 207. See also ECN Investigative Powers Report and Decision Making Powers Report (2012) available at http://ec.europa.eu/competition/ecn/ documents.html. 
evaluation of Regulation 1/2003 in 2009 that the Commission put forward the consideration of soft harmonization or the adoption of certain minimum standards through legislative rules. ${ }^{22}$ Then in 2012, the ECN published its Report on decision-making powers of the NCAs showing a high level of convergence among the NCAs. The Commission considered this convergence a basis for further harmonization of the NCAs' procedures for competition law enforcement. ${ }^{23}$ In 2013, this convergence of national competition law procedures was summarized in the ECN's Recommendations on key investigative and decision-making powers. ${ }^{24}$

In the meantime the ECN's Working Group on cooperation issues and due process was set up that monitored convergence among the Member States and provided an overview of the different systems and procedures for competition law investigations within the ECN. ${ }^{25}$

Despite these developments, national rules still differed on fundamental aspects of the procedures, such as setting priorities, inspecting non-business premises, powers to inspect, to request information or to take commitment decisions, imposing behavioural or structural remedies, procedural rights of parties under investigation, for example, different scope of the privilege against self-incrimination for undertakings, and the enforcement measures and sanctions related to non-compliance with decisions, for instance, some NCAs did not have the power to impose fines directly in case of non-compliance with a commitment decision. ${ }^{26}$

These differences were seen to significantly affect the scope of investigative and decision-making powers of the NCAs (see also: Ost, 2014, pp. 125-136). Moreover, in the area of sanctions, such as fines and the nature of sanctions,

22 European Commission, 'Commission Staff Working Paper of 29 April 2009 accompanying the Report on the functioning of Regulation 1/2003', SEC(2009) 574 final para 207. See also European Competition Network, 'Investigative Powers: Report' and 'Decision Making Powers: Report' of 31 October 2012, available at ec.europa.eu/competition/ecn/documents.html.

${ }^{23}$ European Competition Network, 'Investigative Powers: Report' and 'Decision Making Powers: Report' of 31 October 2012, available at ec.europa.eu/competition/ecn/documents.html.

${ }^{24}$ ECN Recommendation on Investigative Powers, Enforcement Measures and Sanctions in the context of Inspections and Requests for Information, available at http://ec.europa.eu/competition/ ecn/recommendation_powers_to_investigate_enforcement_measures_sanctions_09122013_en.pdf; European Commission, 'Commission Staff Working Document SWD(2014) 231 - Enhancing Competition Enforcement by the Member States' Competition Authorities: Institutional and Procedural Issues', SWD(2014) 230, available at ec.europa.eu/competition/antitrust/legislation/ swd_2014_231_en.pdf.

$\overline{25}$ European Commission, 'Commission Staff Working Document SWD(2014) 231 - Enhancing Competition Enforcement by the Member States' Competition Authorities: Institutional and Procedural Issues', SWD(2014) 230, available at ec.europa.eu/competition/antitrust/ legislation/swd_2014_231_en.pdf.

${ }^{26}$ Ibidem, paras $\overline{45}-4 \overline{6}$. 
there are also differences across the national laws. ${ }^{27}$ Most importantly, it was the ECN that served as a major catalyst in encouraging Member States and/ or NCAs to ensure greater convergence, and the Commission had a dominant role in this so-called 'voluntary' harmonization process. Convergence clearly steered national procedural rules towards the Commission's procedural model. ${ }^{28}$ Best example for this is the ECN Model Leniency Programme, ${ }^{29}$ which closely resembled the Commission's leniency programme ${ }^{30}$, but illustrative examples are also the review process of Article 102 TFEU and sector specific regulations. ${ }^{31}$

However, the effectiveness of these converged and transplanted rules was not always successful in the different institutional frameworks of the Member States. That was visible, for example, in Central and Eastern European (hereinafter: CEE) Member States, where agencies often had to divide resources between several legislative competences and, crucially, depended on institutional capacity. ${ }^{32}$ The ECN Model Leniency Programme, ${ }^{33}$ which has often been praised as a success story of the ECN's cooperation mechanism illustrates this in the CEE countries. The first adopted programmes proved to be unproductive due to insufficient transparency or uncertainty about eligibility. Many programmes had to be revised and are still seen as ineffective in practice. ${ }^{34}$

27 Ibidem, paras 62-77.

28 The 'voluntary' convergence takes place within the ECN's Working Group on cooperation issues and due process, which monitors convergence among the Member States and provides an overview of the different systems and procedures for competition law investigations within the ECN. ECN's Working Group on cooperation issues and due process. Documents available at http://ec.europa.eu/competition/ecn/documents.html.

29 ECN, ECN Model Leniency Programme (2006) available at http://ec.europa.eu/competition/ ecn/model_leniency_en.pdf, accessed 28 April 2014 and the 2012 revision, available at http:// ec.europa.eu/competition/ecn/mlp_revised_2012_en.pdf, accessed 28 April 2014.

30 Communication from the Commission - Amendments to the Commission Notice on Immunity from fines and reduction of fines in cartel cases, OJ C 256/1 (2015).

31 European Commission, 'Commission Staff Working Paper of 29 April 2009 accompanying the Report on the functioning of Regulation 1/2003', SEC(2009) 574 final, paras 248-249.

32 This has been confirmed by the most recent example of Croatia (see: Kapural, 2014, p. 218). NCAs did not enforce the transplanted rules due to constraints in administrative capacity and the enforcement tools have not always delivered the expected results. This is, for example, the case with regard to the power to investigate private premises. There are no actual experiences of the use of this investigative tool in the Czech Republic, Estonia, Hungary, Romania, Slovenia and the Slovak Republic; in Bulgaria it does not exist at all (see: European Commission, Commission Staff Working Paper accompanying the Report on Regulation 1/2003, SEC(2009) 574 final, para 202).

33 ECN, ECN Model Leniency Programme, 2006, available at http://ec.europa.eu/competition/ ecn/model_leniency_en.pdf, accessed at 28 April 2014 and the 2012 revision, available at http:// ec.europa.eu/competition/ecn/mlp_revised_2012_en.pdf.

34 The Czech NCA has applied its leniency programme for the first time in 2004 with regard to a cartel agreement in the energy drinks market. Poland had its first leniency case in a 2006 
While there has been a certain degree of 'voluntary' harmonization towards the Commission's procedural model, the above findings confirm the presence of top-down, rather than bottom-up, processes with hierarchical governance mechanisms. Accordingly, the public consultation initiated by the Commission in 2015 on how to empower NCAs to be more effective enforcers ${ }^{35}$ was a natural consequence of these ongoing hierarchical governance mechanisms pushing towards more convergence among the national enforcement systems.

Ultimately the process resulted in the adoption of the ECN + Directive in 2019.

\section{Implementation of the ECN+ Directive in Hungary}

The paper will analyze more in detail the conceivable changes the Directive generates in the Hungarian legal system and specifically the rules applicable in competition law proceedings.

First a short overview of the recent development of competition law proceedings will be provided.

\section{Development of administrative procedures in competition law cases in Hungary}

Specific investigative and decision-making powers of the Hungarian Competition Authority (Gazdasági Versenyhivatal, hereinafter: GVH) are defined and laid down in the Hungarian Competition Act (hereinafter: HCA) but as a background statute, the Act on the General Rules of Public Administrative Procedures and Services also contains procedural rules. ${ }^{36}$

cartel agreement but had largely revised its 2004 leniency programme in 2009 due to several shortcomings of the previous model. In the Czech Republic, Hungary and Slovakia a marker system exists as well. However, in the Czech Republic the decision to grant a 'marker' lied fully at the discretion of the NCA. In Hungary, leniency was applied for in a few cartel cases yet only one of them has already been closed by the NCA in 2007 (Vj-81/2006). Nagy shows that in Hungary the annual number of leniency applications is fairly low (see: Nagy, 2016 A, p. 107).

35 European Commission, 'Empowering the national competition authorities to be more effective enforcers' http://ec.europa.eu/competition/consultations/2015_effective_enforcers/ index_en.html.

$36{ }^{-}$Act CXL of 2004 on the General Rules of Public Administrative Procedures and Services. The provisions of this Act need to be applied to the procedures of the GVH only when the Competition Act, which contains specific procedural rules applicable to the GVH, does 
Throughout the past decade various amendments of the HCA have brought competition law procedures in close compliance with the new provisions of the Directive. Therefore, it has now been argued that only certain rules need to be introduced in order to achieve full conformity with the Directive (Szilágyi, 2019, pp. 51-57). This means that the GVH already possesses many of the vital instruments and powers that are necessary to effectively enforce competition law. Key amendments have taken place in $2014^{37}$ and $2017^{38}$.

At the same time, it has been argued that in the past 5 years 10 amendments have been passed to the HCA, which has resulted in a fragmented piece of legislation (for example Article 88 has sections from A-V on civil law claims). The question arose whether a new modern competition act should be considered that is fit for the challenges of the 21 Century. ${ }^{39}$

The current procedural framework is in general quite similar to the investigative and decision-making powers of the Commission. However, the investigation and decision making powers are separated within the GVH. The decision-making body of the GVH is the Competition Council (hereinafter: CC) - under the management of one of the Vice Presidents of the GVH, who is at the same time the Chair of the CC. The CC is a quasi-judicial body and it decides each case by a three-member (exceptionally five-member) panel designated by the Chair of the $\mathrm{CC}$ and its members act with full autonomy. They cannot be instructed and they are subordinated exclusively to the law. ${ }^{40}$ Criminal punishments can be applied in Hungary in competition law cases

not contain any rules different to the provisions of the Act on the General Rules of Public Administrative Procedures and Services.

37 Act CCI of 2013 among others affected the types of procedures (upon application or on own initiative), stages of proceedings and the procedural position of the persons entitled to access documents, as well as establish a coherent system of access to documents that is sufficiently differentiated to accommodate various types of data. In the context of the protection of business secrets, the amended Competition Act allows the GVH to grant access to business secrets or certain other privileged information of the other party, with due consideration to the rights of the data owner and to the protection of other privileged information and the statutory rights of the party requesting access, in particular the conflicting rights to defence and to a legal remedy, with appropriate practical restrictions and secrecy obligations where required and following consultation with the parties concerned. See more Annual Report GVH 2014.

38 The most significant of these changes relates to the re-regulation of the procedures affecting the control of concentration of undertakings. Another major area of amendment was the transposition of Directive 2014/104/EU of the European Parliament and of the Council on actions for damages for infringements of the competition law provisions. Act CXXIX.of 2017.

$39 \mathrm{http} / / /$ competition.hu/versenyjog/a-versenytorveny-menetrendszeru-valtozasai/.

40 OECD, Roundtable on changes in institutional design of competition authorities, note by Hungary (2014) DAF/COMP/WD(2014)123. The members of the CC are lawyers or economists (or have both qualifications). There must be at least one economist among the members of the decision panel for every case. 
regarding public procurement and concessional cartels (Nagy, 2016 A, 139 ff.). In these procedures, it is not the $\mathrm{GVH}$ who conducts the investigations but the Public Prosecutor's Office in cooperation with the police, and the criminal court is the decision-making judicial entity (Nagy, 2016 A, 145). Natural persons involved in these cartels may face imprisonment of up to five years (Nagy, 2016 A, 140).

Concerning priority setting, NCAs have in general broad discretion to decide whether to investigate a certain case and to impose a fine. The GVH may set priorities and is not obliged to investigate all alleged violations of competition law. As the GVH used to receive a significant number of irrelevant complaints, in 2005 the complaint system was substantially reformed. Since 2005, complaints can be submitted to the GVH via a form requesting a relatively broad range of information. According to the reformed system, it is no longer necessary for the complainant to be concerned by the suspected violation of competition law. In this system complainants have special rights (for example, to challenge a decision of the $\mathrm{GVH}$ rejecting a complaint). ${ }^{41}$

According to Article 70 (1) HCA, the GVH only has the obligation to start an investigations in case the protection of the public interest warrants this, but has a margin of appreciation to decide when this requirement is fulfilled. The decision not to investigate a case can be appealed in court if the case was started on the basis of a formal complaint of a third party. ${ }^{42}$

The GVH has set up beyond its Cartel Unit a separate unit, the Cartel Detection Unit, which is responsible for the detection of cartels and also gathers, analyses, and processes all the information that is necessary for the initiation of competition supervision procedures; furthermore, it carries out unannounced inspections ('dawn raids'). ${ }^{43}$

Once an investigation starts, the GVH has the following investigative measures when it acts during competition proceedings: request for information, hearing of witnesses, access to documents, on-site inspection without a prior notification based on a judicial authorisation, at the headquarters of the undertaking or at private premises, seizure, sealing or the making of forensic images of the computer database. ${ }^{44}$ The undertaking also has the duty to

41 The possibility to submit indications ('informal complaints') to the GVH, that do not have to comply with the requirements for complaints, still exists. However, 'informal complainants' do not have the same rights as complainants. OECD, Roundtable on changes in institutional design of competition authorities, note by Hungary (2014) DAF/COMP/WD(2014)123.

42 Article 43/H and $82 \mathrm{HCA}$.

43 OECD, INVESTIGATIVE POWER IN PRACTICE - Breakout session 1 - Unannounced Inspections in the Digital Age - Contribution from Hungary, DAF/COMP/GF/WD(2018)65.

44 Sections 55, 55/A, 65, 65/A(1) HCA. 
cooperate (Section 64B (I) GVH. See also: Nagy, 2016 B, pp. 192-204). In most EU Member States, the NCA has the possibility to impose a fine after the investigations phase, which is also the case in Hungary (this is different in Austria, Ireland, Denmark, Finland and Sweden).

\section{Changes necessary for the implementation of the Directive}

Articles 6-12 of the ECN+ Directive concern common investigative and decision-making powers and Hungarian legislation already complies with the Articles 6-9 on inspection of business premises and other premises, request for information and taking interviews. These provisions are laid down in Articles 64 (A-F) and 65 (A-D) GVH and provide wide investigative powers for the GVH in its investigations (Nagy, 2016 A, p. 94).

The Hungarian legislator will need to address, however, the finding and termination of infringement under Article 10, which HCA concerning decisions of the GVH does not preclude the possibility to impose behavioural or structural remedies. However, the HCA could specifically implement this possibility of taking decisions for behavioral and structural remedies in cases concerning agreements and abuse (Szilágyi, 2019, p. 53-54). Article 11 of the Directive addresses interim measures. The Hungarian Competition Act also regulates interim measures in its Article 72/A HCA, however, the conditions for taking these measures differs from the Directive; Hungarian legislation needs adjustment concerning the Directive's provisions that state that decisions on interim measures shall be proportionate and apply for a specified time period, which can be renewed when it is necessary and appropriate, or until the final decision is taken.

\subsection{Commitments}

Article 12 of the Directive addresses commitments. Commitments are regulated in Article $75 \mathrm{HCA}$. In fact, the Directive has implemented provisions (monitoring and reassessing commitments) that had already been part of Hungarian law (Szilágyi, 2019, p. 54). The GVH is entitled to conduct a so-called follow-up assessment to establish whether the commitments have indeed been complied with. Commitments were introduced in the HCA in 2005 and have been frequently adopted by the CC of the GVH. It has, in fact been criticized to be a substitute for private enforcement (Nagy, 2016 A, p. 117; Bassola, Kékuti, Marosi, 2011). A recent example can be found in commitments offered by Wizz Air Hungary Zrt. where, as a result of the 
commitments, customers affected by the operation of the Wizz Flex service of Wizz Air since 2010 receive compensation and the company also undertook to change its information practices. ${ }^{45}$

\subsection{Fines}

The powers of the NCAs concerning fines are laid down in Articles 13-16 of the Directive. The Directive now harmonizes the fundamental principles of national fining policies, in order to eliminate divergences in fining policies that may prevent the effective enforcement of EU competition law. The Directive addresses an enforcement gap that relates to the cross-border enforcement of decisions imposing fines. This gap was at the heart of a Hungarian case, where the GVH fined Siemens Austria AG in the Hungarian gas insulated switchgear cartel. ${ }^{46}$ Due to the lack of availability of an appropriate cooperation mechanism under Regulation 1/2003, the GVH brought an action for the recovery of the interest that was due to be paid by Siemens, on the ground of undue enrichment in Hungary. ${ }^{47}$

Many Member States' fining policies and several national fining rules already comply with the provisions of the Directive. Láncos shows that most Member States' policies even go beyond the Directive, closely aligning the details of their fining rules to the Commission's guideline on fines (Láncos, 2019). The Hungarian fining rules, as laid down in the HCA and the GVH's 2017 communication on fines to be imposed in cartel and abuse of dominant position cases in late $2017^{48}$, have already been well aligned to the Commission's guideline on setting fines, adopting both the substantive thresholds and consideration of gravity and duration enshrined therein (Láncos, 2019).

45 Decision VJ/17/2017. http://www.gvh.hu/en/press_room/press_releases/press_releases_ 2019/commitment_decision_taken_by_the_gvh_in_the_wizz_a.html; See other cases in the area of unfair commercial practices: https://www.schoenherr.eu/publications/publication-detail/ hungary-hcas-recent-practice-cooperation-and-commitments/.

46 C-102/15 Gazdasági Versenyhivatal v Siemens AG. ECLI:EU:C:2016:607.

47 Para 20.

48 A Gazdasági Versenyhivatal elnökének és a Gazdasági Versenyhivatal Versenytanácsa elnökének 11/2017. közleménye a versenykorlátozó megállapodásokra és összehangolt magatartásokra, a gazdasági erőfölénnyel való visszaélésre, valamint a jelentős piaci erővel való visszaélésre vonatkozó tilalmakba ütköző magatartások esetén a bírság összegének megállapításáról (Communication No. 11/2017 of the President of the Competition Authority and the Chair of the Competition Council of the Hungarian Competition Authority on the setting of the amount of fines in case of anti-competitive agreements and concerted practices, the abuse of dominant position and the abuse of significant market power). 
Hungarian law will need adjustment only concerning the rules of Article 14(4) on defining liability for fines. Accordingly, to prevent undertakings escaping liability for fines for infringements of Articles 101 and 102 TFEU through legal or organizational changes, NCAs should be able to find legal or economic successors of the undertaking liable, and to impose fines on them, for infringements of Articles 101 and 102 TFEU.

\subsection{Leniency}

Concerning leniency the Directive sets a number of fundamental rules in Articles 17-23. These provisions require Member States to adopt leniency programmes that follow the Commission's Leniency Notice (Articles 17-20), and to establish a system of markers and summary applications (Articles 21, 22). The HCA, and the GVH's leniency policy laid down in soft law instruments, have converged in great detail with the Commission leniency policy and the ECN Leniency Model throughout the past 16 years.

Leniency policy in Hungary was introduced in 2003 and its main provisions were stipulated in the HCA. The detailed leniency policy was implemented in the form of a Notice of the GVH (Notice No 3/2003 on Leniency), which was not legally binding, but defined the guiding principles and the extent to which the active cooperation of a company suspected of engaging in a cartel activity should be taken into account. ${ }^{49}$

The relevant provisions of the HCA were amended in 2006 and more substantially in 2009, with the latter amendment taking into account the ECN's Model Leniency Programme. The leniency policy was then incorporated into hard law, into the provisions of the HCA. The HCA stipulates the basic rules, while the Notice on Leniency Policy contains the detailed rules on leniency. The marker system was introduced in Hungary by this amendment also. The next amendment of 2013 was to align the leniency rules with other provisions of the HCA and to harmonize the Hungarian leniency policy with the new ECN Model Leniency Programme revised in 2012. With the amendment of 2016, which entered into force in January 2017, the scope of the leniency policy was extended to hard core vertical agreements and concerted practices aimed at directly or indirectly fixing purchase or sale prices. ${ }^{50}$

Even though the Hungarian leniency programme is fully harmonized with the ECN Model Leniency Programme, and the new developments of the European Commission's practice are already incorporated, the number of

49 OECD, Roundtable on challenges and co-ordination of leniency programmes - Note by Hungary, 5 June 2018, DAF/COMP/WP3/WD(2018)4, p. 1-2.

50 OECD, Roundtable on challenges and co-ordination of leniency programmes - Note by Hungary, 5 June 2018, DAF/COMP/WP3/WD(2018)4, p. 2. 
leniency applications was very low and the leniency policy has been criticized as being ineffective in Hungary. ${ }^{51}$

The next section will analyze the institutional aspects of the Directive and its implementation in Hungary

\section{Institutional issues: independence and accountability}

Regulation 1/2003 has not specified any sort of requirements on the formal independence of NCAs. ${ }^{52}$ As a consequence of the principle of institutional autonomy, the Member States are free to design their own enforcement system (See Scholten, Ottow, 2014). The designated NCAs could, therefore, be administrative or judicial in nature. The Member States were obliged to set up a sanctioning system providing for sanctions which are effective, proportionate and dissuasive for infringements of EU law. ${ }^{53}$

Political independence of the NCAs is now implemented as one of the cornerstone provisions of the Directive in Article 4. The Article formulates minimum requirements of independence; it requires that an express provision is made in national law to ensure that when applying Articles 101 and 102 TFEU, NCAs are protected against external intervention or political pressure liable to jeopardize their independent assessment of matters coming before them. ${ }^{54}$ Article 4 of the Directive lays down specific rules concerning independence, most importantly that NCAs should be performing their tasks independently from political and other external influences. The proposal for the Directive was in fact justified among others, by the need to ensure that

51 As regards the reasons for the relatively low number of leniency applications, the cultural aspect is deemed to be one of the most relevant: i/ cultural background, as an effect of the formerly 'planned' economy system of Hungary (not to be seen as a traitor) and ii/ low level of competition law awareness (especially in the case of SMEs). In order to improve this situation, the GVH launched a communications campaign to raise awareness, educate, and incentivize. OECD, Roundtable on challenges and co-ordination of leniency programmes - Note by Hungary, 5 June 2018, DAF/COMP/WP3/WD(2018)4, p. 3.

52 Case C-53/03 Syfait [2005] ECR I-04609, paras 31-36. In 2010, a Hungarian Court refused to examine whether the legal basis on which immunity had been granted to one of the undertakings was appropriate, as the fine imposed on the appellant resulted from its own infringement of competition rules, not from the other undertaking receiving immunity, Hungarian Metropolitan Court of Appeal (Fövárosi Ítélótábla), Kortex Mérnöki Iroda Kft. v Competition Authority, Case n².Kf.27.408/2010/5, 17 November 2010.

53 Point 2 Network Notice. See also Case C-176/03 Commission of the European Communities $v$ Council of the European Union [2005] ECR I-7879, paras 46-55.

54 Recitals 14-16 Directive. 
NCAs have the necessary guarantees of independence. ${ }^{55}$ The preamble now says that national law can prevent NCAs from being sufficiently independent and having effective tools to detect infringements and impose effective fines on companies for infringements of EU competition rules. The independence of NCAs is to be strengthened by the Directive in order to ensure the effective and uniform application of Articles 101 and 102 TFEU.

The basic idea that institutions matter for economic development is founded on the assumption that institutional frameworks create incentives for behaviour, leading to different outcomes. North defines institutions as the rules that determine the behaviour of individuals and organizations. ${ }^{56}$

\section{Relevance of institutions}

It is well recognized in competition law that institutions are a critical driver of public policy and law enforcement that interact, in many indirect ways, with substantive rules (Crane, 2011). The interaction of the institutional design of competition law enforcement with substantive rules and policy-making has by now been extensively discussed in competition law (see: International Competition Network, Report on the Agency Effectiveness Project Second Phase - Effectiveness of Decisions Prepared by The Competition Policy Implementation Working Group, Presented at the 8th Annual Conference of the ICN Zurich, June 2009; Fox, 2010; Fox, 2012; Hyman, Kovacic, 2012).

It has been argued that the institutional embededness of legal rules involves important procedural and institutional complexities and irregularities that influence effective law enforcement. Substantive rules and policies are mediated through the institutions that investigate, enforce and adjudicate legal issues and the decision-making processes that these institutions employ. Institutional and procedural differences are likely to generate widely different substantive outcomes, even with a similar legislative mandate. The respective institutional contexts will each shape decisions in their own ways and may lead to differing functions of the legal rules and thus potentially very different outcomes (Gerber, 2008).

55 Proposal for Directive to empower the competition authorities of the Member States to be more effective enforcers and to ensure the proper functioning of the internal market.

Brussels, 22.03.2017 COM(2017) 142 final p. 3.

56 North distinguishes between formal rules such as laws and regulations and informal rules such as constraints on behaviour derived from culture, tradition, custom and attitudes. Formal rules and informal constraints are interdependent and in constant interaction (see: North, 1990). 


\section{Independence in EU law}

The independence of regulatory agencies has been traditionally justified by the technical complexity of the regulated markets, and thus the need for expert decision-making. An agency should be insulated from short-term political pressures in order to adopt public policies based on expertise - that is, to bring expertise-driven independent decision-making to the administrative state. It was believed to yield better public policy over the long term (Barkow, 2010). Consequently, the concept of independence builds on the regulator's legal and functional separation from market parties and its independence from the legislative and executive powers.

The basic design of democratic institutions, and thus the design of competition authorities, should be based on independence, neutrality, transparency, political and judicial accountability, and respect for the separation of powers. The independence of competition authorities is a critically important aspect of certainty and transparency, and ultimately affects the legitimacy of a country's competition law in the eyes of both business and its citizens. ${ }^{57}$

While in the US the concept of independence traditionally implied the US President's limited interference in the operation of independent agencies and the need for expert decision- making (Landis, 1938), in the EU the concept has been less clear-cut and developed mostly at national level independently from EU law requirements (Hanretty, Larouche, Reindl, 2012).

EU law has, in other fields of economic regulation, focused on the independence of national regulatory agencies from market players. ${ }^{58}$ However, while EU law is considerably detailed concerning the concept of independence, and EU Courts emphasized the importance of independence in the context of regulated markets, ${ }^{59}$ the Courts have, so far, not formulated any general

57 Independence from the government can have a considerable impact on market stability and the facilitation of investment. Independence is essential in order to avoid competition law being used to achieve political or industrial goals that have little to do with the broader goals of efficiency, referenced above. These outcomes are significant features of a properly functioning democracy, governed by the rule of law. Independence from government politics 'de-politicizes enforcement decisions, reduces the risk of perceived bias, and provides consistency from one political term to the next.' Competition and Democracy, Contribution by BIAC, DAF/COMP/ GF/WD(2017)1, p. 6 (see also: Ottow, 2015).

58 It was in 1988, in Directive 88/301 on competition in the markets in telecommunications terminal equipment that the Commission introduced in Article 6 an obligation on the Member States to entrust the regulation of terminal equipment to a body independent from market parties active in the provision of telecoms services or equipment. This requirement of independence has also been implemented in the second liberalization package in the energy and telecoms sector.

59 See Case C-202/88 France v Commission [1991] ECR I-1223, paras 51-52; Case C-18/88 RTT v GB-Inno-BM [1991] ECR I-5973, paras 25-26; Case C-82/07 Comisión del Mercado de las Telecomunicaciones [2009] ECR I-1265. 
principles on the independence of regulatory authorities. ${ }^{60}$ Accordingly, while EU law requires regulators to be independent from political institutions, it has not laid down the criteria of independence that regulatory authorities must meet (Hanretty, Larouche, Reindl, 2012).

Regulation 1/2003 did not specify any kind of requirements on the formal independence of NCAs. ${ }^{61}$ Still, political independence from central government may not be guaranteed in all countries, a fact that can be problematic as competition authorities have to use their expertise independently from political and market actors.

The most comprehensive study on the issue of the formal independence of NCAs is likely in the work of Guidi, who shows extensive variations in independence among the NCAs. However, Guidi's study raises the question of how does a NCA's de iure independence reflect its de facto independence (Guidi, 2011; Guidi, 2014). The difference between de iure and de facto independence is crucial as Member States' implementation may raise questions with regard to the Directive's provisions on independence. The next sections will analyze how the GVH complies with the Directive's provisions on independence and the accountability mechanisms.

\section{Independence of the GVH}

The Hungarian GVH is a budgetary institution and is independent from the Government: it cannot be given instructions by any governmental institution but is only bound by law. The operation and financial management of the GVH

60 The 2009 package of liberalization mentions a general principle of independence towards the legislative and executive organs. Article 35 of Directive 2009/72 on electricity compels Member States to make the regulatory authority 'functionally independent from any other public or private entity' and give it the autonomy to decide 'independently of any public body'. The new Directive on the internal market for eletricity requires regulatory authorities to be independent. Article 57 of Directive 944/2019. Regulatory authorities need to be able to take decisions in relation to all relevant regulatory issues if the internal market for electricity is to function properly, and need to be fully independent from any other public or private interests. This precludes neither judicial review nor parliamentary supervision in accordance with the constitutional laws of the Member States. In addition, the approval of the budget of the regulatory authority by the national legislator does not constitute an obstacle to budgetary autonomy. The provisions relating to the autonomy in the implementation of the allocated budget of the regulatory authority should be implemented in the framework defined by national budgetary law and rules. While contributing to the regulatory authorities' independence from any political or economic interest through an appropriate rotation scheme, it should be possible for Member States to take due account of the availability of human resources and of the size of the board.

61 Case C-53/03 Syfait, judgment of 31 May 2005, paras 31-36. 
is completely autonomous and constitutes a separate chapter in the central budget. ${ }^{62}$

The President of the GVH is nominated by the Prime Minister, heard by the Hungarian Parliament and is appointed by the President of Hungary. The Vice-Presidents are appointed by the President of Hungary, who, at the same time, entrusts one of the two Vice-Presidents with the responsibilities of the Chair of the Competition Council. The President and Vice-Presidents are appointed for a term of six years. After the expiry of the six-year period such appointments may be renewed, with the proviso that the Chair of the Competition Council may be reappointed only once. The President of the GVH cannot be dismissed except in specific and very serious circumstances. ${ }^{63}$ In 2010, an amendment to the HCA specified that the appointment of the Vice-presidents will coincide with that of the President. The term of the then GVH President was to expire in 2010. The Vice-presidents term would have run until 2015. The amendment of the HCA was subject to a constitutional complaint to the Hungarian Constitutional Court. ${ }^{64}$ The autonomy of the GVH is to protect it from direct influence from the government and market parties and is, among others, clearly safeguarded by the term of office of its president and vice-presidents (Iancu, Tănăsescu, 2019). Even though the Constitutional Court argued that the GVH's autonomy is constitutionally protected and anchored in the fixed term of office of its President and Vice-Presidents and the amendment to the HCA was not justified, the Vice-Presidents resigned voluntarily. This was certainly a relevant setback to the GVH's autonomy.

The GVH is held accountable to the Hungarian Parliament. As mentioned above, its President is heard by the Parliament before his or her appointment. Moreover, the GVH submits its annual reports to the Parliament and, on request, to the competent parliamentary committee on the activities of the GVH. In addition, according to Article $35 \mathrm{HCA}$, the GVH has to publish the non-confidential versions of all of its decisions and all of its final orders adopted at the conclusion of proceedings (the opening of which were also made public). Finally, the National Audit Office controls how the GVH uses its financial resources. ${ }^{65}$

Accordingly, de iure the GVH is independent and complies with the new provisions of the Directive. However, when examining its independence in

62 Article 33/A HCA.

63 Article 35 GVH, Article 35/A, Article 38 GVH.

64 Decision of the Constitutional Court 183/2010. (X.28) AB.

65 Act No. CXCV. of 2011 on Public Finances, Government Decree 368/2011. (XII. 31.) on the rules of operation of public finances and Government Decree 4/2013. (I. 11.) on public accounting. 
the current broader constitutional and political context of Hungary, questions arise as to its de facto independence.

In general, the perceived quality and effectiveness of legal and political institutions in Hungary has been weak. ${ }^{66}$ In 2018, Hungary ranked 60th among 137 countries in the institutional component of the Global Competitiveness Index, however, its institutions scores much lower at 101th. ${ }^{67}$ Besides administrative burdens, predictability and transparency in policy-making and the efficiency of the legal framework in enabling firms to challenge government regulations are seen as particularly problematic. ${ }^{6}$

In 2019, the European Semester Country Report testified that Hungary's institutional capacity needs to be improved as there are fast and unpredictable changes in regulations and the transparency of policy-making is limited. There are significant regulatory barriers and state involvement including new monopolies and ad hoc exemptions from competition scrutiny. ${ }^{69}$ Public authorities continue to entrust certain services to state-owned or private firms specifically created for these purposes (for example, textbook publishing, waste collection, mobile payments, tobacco wholesale and retail).

Specifically, a number of cases in the past seven years raised serious concerns about the GVH's independence from direct political influence of the government. Two landmark cases will be analyzed here: the exemption of mergers of national strategic importance and the so-called Watermelon cartel case.

In 2013 a new provision was introduced in the Hungarian Competition Act. Article 24/A of the Competition Act states that the Hungarian Government 'may, in the public interest, in particular to preserve jobs and to assure the security of supply, declare a concentration of undertakings to be of strategic importance at the national level.' For these types of concentrations, no authorization of the GVH is required. Moreover, the decision can be taken via a government regulation which is not subject to judicial review. Until 2018, 21 merger cases, in the area of energy, finance, telecommunications, IT and transport, were approved by the government without having the GVH authorize them on the basis of their impact on competition. ${ }^{70}$ In November 2018, the government has declared the creation of a media conglomerate

66 A stable and efficient legal framework, grounded on the principles of separation of powers and judicial independence, is widely seen as improving economic growth (see: North, 1990; Rodrik, Subramanian, Trebbi, 2004, pp. 131-165).

67 World Economic Forum, 2017-2018. https://www.weforum.org/reports/the-globalcompetitiveness-report-2017-2018.

68 OECD, Economic Surveys: Hungary, 2014, p. 29.

${ }^{69}$ European Semester, Country report, 2019, Hungary p. 37-39.

70 European Commission, Country report, Hungary, 2015. 
with Government Decree 229/201871 of 'national strategic importance in the public interest,' and with a decree it called for exempting the merger affecting hundreds of broadcast, online and print publications from competition rules. In its B/961/2018 Decision, the GVH declared that it has no competence to conduct a merger control review. ${ }^{72}$ The merger conglomerate was thus not scrutinized by the GVH due to Article 24/A. The merger comprised a foundation to which 10 companies donated media outlets. Through the concentration, the foundation controls nearly 480 publications and their operations are run by a publisher known for his loyalty to the Hungarian prime minister. The foundation resembles a massive advertising and readership centre, which was not allowed to be formed until now under market rules. The merger of the media companies into the foundation and its exemption from competition rules reflects a large scale concentration of governmental power.

Even though the debate about the conflict between achieving efficiency considerations and public interest policy objectives through competition has intensified in recent years, as governments more frequently intervene in markets of significant national importance through a variety of tools, including arranged mergers and foreign investment rules, ${ }^{73}$ the present Hungarian rules on exempting mergers is unprecedented.

The exemptions are issued through government decrees and thus cannot be challenged in court and thus be submitted to a legal review. A 2016 OECD Report shows that merger exemptions on public interest ground are common in other OECD countries too, but they are implemented only after full merger reviews by competition authorities and they are based on clear and explicit public interest grounds. ${ }^{74}$ These exemptions are also quite rare. For comparison, Germany has exempted less than 10 mergers over the past 30 years. Hungary had put at least 21 exemptions in place between 2013 and 2018 as mentioned above. Most of these mergers in Hungary were relatively small and would probably have been cleared by the competition authority if subjected to a merger review.

The second case to be discussed here is the so-called Watermelon case. This case is_the most criticized example of exempting allegedly anti-competitive practices by legislation from the enforcement of competition rules. ${ }^{75}$ This case

71 229/2018 (XII. 5.) Korm. Rendelet.

72 http://www.gvh.hu//data/cms1039707/Osszefoglalo_B961_2018.pdf

73 OECD, Public interest considerations in merger control, DAF/COMP/WP3(2016)3.

${ }^{74}$ In many jurisdictions (FR, GER, IT, NL, UK) the government (usually the minister of the economy) has the power to intervene in merger control. Such intervention is often ex post as it follows the competition authority's own assessment and is based on public interest clauses which allow the competition authorities' decision to be overruled. See: OECD, Public interest considerations in merger control, DAF/COMP/WP3(2016)3.

75 Case Vj-62/2012. 
also questions how effectively the ECN safeguards the enforcement of EU competition rules and whether the EU Commission could have played a more forceful monitoring role.

In 2012, the GVH initiated a competition supervision procedure against a number of Hungarian melon producers, the Hungarian Melon Association and the Inter-branch organization for fruits and vegetables (Hungarian Interprofessional Organisation for Fruit and Vegetables) concerning an alleged infringement of the prohibition on restrictive agreements. The parties had allegedly agreed on a "fair" minimum price that would be charged from July 2012 for watermelons produced in Hungary and that they would restrict the distribution of imported watermelons. The alleged agreement was initiated by the Ministry for Rural Development, who wanted to secure a fair standard of income for farmers through this action. ${ }^{76}$

After the GVH started its investigation, the Hungarian Parliament adopted an amendment to the Act on Inter-branch Organisations. ${ }^{77}$ This amendment stated that subject to the approval of the Minister for Agriculture and Rural Development, an otherwise restrictive agreement in the agricultural sector could be exempted from the prohibition of anti-competitive agreements under Hungarian competition law. The Minister must ensure that the restrictive agreement guarantees a fair income for the producers and that all market actors are equally allowed to join it. ${ }^{78}$ In addition, the amendment stated that the GVH must (a) suspend imposing a fine for anti-competitive practices in violation of Article 11 of the Competition Act or Article 101 TFEU conducted with respect of agricultural products and (b) call the involved parties to act in compliance with the applicable laws. If such parties fail to comply within the deadline set by the GVH, the GVH is entitled to impose a fine on them.

The amendment had substantial consequences. The GVH terminated its proceedings in the Watermelon case after the Minister had found that the conditions for the exception were met. ${ }^{79}$ The GVH also closed its investigation in the Sugar cartel case, in which it suspected that sugar producers had

76 http://www.gvh.hu/en/press_room/press_releases/press_releases_2013/8198_en_termina tion_order_was_issued_the_end_of_the_watermelon_saga.html

$\overline{77}$ Act $\bar{N}$ o. $\bar{C} L X X \overline{V I}$ of 2012 on inter-branch organisations and on certain issues of the regulation of agricultural markets adopted on November 19, which amended Act CXXVIII of 2012.

78 Agricultural Organizations Act, Article 18/A(1) provided that:'The infringement of Section 11 of the Competition Act cannot be established in case of agricultural products if the distortion, restriction or prevention of competition resulting from an agreement according to Section 11 of the Competition Act does not exceed what is necessary for an economically justified, fair income, provided that the actors of the market affected by the agreement are not debarred from benefiting from such income and that Article 101 TFEU was not applied.'

$79 \mathrm{Vj}-62 / 2012$ paras $13-15,42-46$ and 56-57. 
regularly coordinated their market behaviour with respect to prices, divided their industrial and retail purchasers, and shared information related to the quantities sold. ${ }^{80}$ The GVH has been vigorously enforcing competition rules and, most notably, the cartel provision in the agricultural sector before 2012 . In fact, price-fixing and market-sharing decisions of agricultural associations were among the most frequent types of GVH cartel cases. ${ }^{81}$ The ECN's 2012 study of the food sector shows that in the period 2004-2011 the GVH had investigated and closed 11 cases, which is a relatively high number and places Hungary as the $8^{\text {th }}$ most active enforcer among the Member States. ${ }^{82}$ According to a 2018 study by the Commission on the application of EU competition rules to the agricultural sector, Hungary investigated only one single case in the agricultural sector in the period of 2012 and 2017. ${ }^{83}$

Despite heavy criticism of the exemption by both academia (Csépai, 2015, pp. 404-405; Toth, 2013, pp. 364-366) and international organizations (Pina, 2014, p. 16) as well as by the GVH itself, ${ }^{84}$ the European Commission had not questioned the exemption itself. It only focused on the provisions that did not allow the GVH to impose fines where the agreement affected trade between Member States. The European Commission issued a reasoned opinion requesting Hungary to ensure effective enforcement of competition law regarding agricultural products and to comply with its competition law obligations under EU law. ${ }^{85}$

In this opinion the Commission emphasized that since 2004, the Commission and the NCAs share parallel competences for the enforcement of EU competition law. They cooperate in the ECN to exchange information and inform each other of proposed decisions to ensure an effective and consistent application of EU competition rules. ${ }^{86}$ Threatened by possible initiation of an infringement procedure against Hungary, the Hungarian Competition Act was changed in 2015. Its new Article 93/A clarified that the GVH may impose

$80 \mathrm{Vj}-50 / 2009$ (sugar cartel), paragraph 132.

$81 \mathrm{Vj-199/2005} \mathrm{Egg} \mathrm{cartel} \mathrm{(2006),} \mathrm{Vj-69/2008} \mathrm{wheat} \mathrm{mill} \mathrm{products} \mathrm{I} \mathrm{(2010);} \mathrm{Vj-89-2003/58}$ hunting cartel (2004).

82 ECN Subgroup Food. ECN Activities in the Food Sector. Report on competition law enforcement and market monitoring activities by European competition authorities in the food sector, May 2012; https://ec.europa.eu/competition/ecn/food_report_en.pdf

83 Commission Staff Working Document. Accompanying the document Report from the Commission to the European Parliament and the Council The application of the Union competition rules to the agricultural sector $\{\operatorname{COM}(2018) 706$ final $\}$, Brussels, 26.10.2018 SWD(2018) 450 final, p. 33.

84 Vj-62/2012 watermelon (2013), para 70-72, GVH - The GVH suggests enforceable ethical rules to the agricultural sector, 29.9.2009.

85 http://europa.eu/rapid/press-release_MEMO-14-293_en.htm.

$86 \mathrm{http} / / /$ europa.eu/rapid/press-release_MEMO-14-293_en.htm. 
sanctions, including fines, when the agreement infringes EU competition law. The 2015 amendment of the Competition Act introduced Article 93/A that explicitly stipulates that the provisions which regulate the specificities of agriculture, and which were originally part of Act CXXVIII of 2012 on agricultural associations and on the regulation of certain issues concerning the agricultural markets (Act on inter-branch organizations), are only applicable if the primacy of the competition rules of the EU does not prevail. ${ }^{87}$ The Commission has accordingly closed the case in 2015 without further actions from the Commission. Even though questions arise with regard to the Commission's own case, the point here is the concern how the government can use the mechanism of legislation to bind the hands of the GVH in cases where competition law should be enforced. Moreover, an additional concern is that the decision of the minister is not open to a judicial challenge.

In this generally weak institutional governance framework competition has been often explicitly limited by legislation. ${ }^{88}$ In this poorly performing institutional environment and where the low intensity of competition has been criticized for many years (Tóth, Hajdu, 2017), one has to conclude that the GVH has de facto become dependent on a legally constrained enforcement framework that limits its autonomy as an enforcer of competition rules. Additionally, independence has to be investigated in relation to political and judicial accountability. This will be the subject of the next section.

\section{Accountability of the GVH}

The NCAs can be held accountable by their national parliaments for their EU competition law enforcement. The scope of the accountability and its procedures are largely determined by country-specific legislation and the respective legal traditions. Article 4 of the Directive does not add a substantive provision in this regard. It simply states that Member States should subject their NCAs to proportionate accountability requirements, without defining further details of what these requirements are. The accompanying text does, however, indicate that proportionate accountability requirements include the publication by NCAs of periodic reports on their activities to a governmental

87 Article 93/A. (5) para (1)-(4) shall only apply to a case if the necessity of the application of Article 101 TFEU does not arise. The necessity of the application of Article 101 TFEU shall be established by the Hungarian Competition Authority in its competition supervision proceeding pursuant to Article 3(1) of Council Regulation (EC) No 1/2003, before making the final resolution. GVH, Annual Report, 2015. http:/www.gvh.hu/en//data/cms1035410/ gvh_ogy_pb_2015_a.pdf.

$\overline{88}$ European Semester, Country report, 2019, Hungary p. 39-40. 
or parliamentary body. NCAs may also be subject to control or monitoring of their financial expenditure, provided this does not affect their independence.

In general, accountability mechanisms weakened in the past years in Hungary. The deterioration is particularly notable in Hungary concerning voice and accountability, control of corruption and regulatory quality. Corruption risks and weak accountability distort the allocation of resources as these are not necessarily channelled to the most productive firms. ${ }^{89}$

The GVH has been publishing and submitting its annual reports ever since its creation in 1991 to the Hungarian Parliament ${ }^{90}$, where various Committees such as the Economic and Consumer protection Committees have pre-discussed and commented on the reports and the Parliament has held general debates with the participation of the representative of various parties. The GVH's work used to be praised and appreciated by the Members of the Hungarian Parliament (both government and opposition parties) and they voiced their satisfaction with the transparency and accuracy with which the GVH worked and communicated its work to the outside world. ${ }^{91}$

However, since 2010 accountability mechanisms significantly weakened. When the new chairman of the GVH was appointed by the government in 2010, he was not heard by the Parliament before his appointment. ${ }^{92}$

A discursive analysis of the Hungarian parliamentary debates on the GVH's annual reports in the period 2004-2018 revealed a serious 'backsliding' of the accountability mechanisms in Hungary.

The discursive analysis of general parliamentary debate reveals that the general debates no longer provide the forum to hold the GVH accountable for its enforcement work. The GVH's annual reports have not, since 2012, been subject to a general debate in the Parliament but were merely discussed within one single Parliamentary Committee, the Economic Affairs Committee. ${ }^{93}$

89 European Semester, Country report, 2019, Hungary p. 41.

90 See annual reports in English: http://www.gvh.hu/gvh/orszaggyulesi_beszamolok, accessed 8 December 2016.

91 See Parliamentary debates on the GVH's Annual reports, J/15947 A Gazdasági Versenyhivatal 2004. évi tevékenységéről és a versenytörvény alkalmazása során szerzett, a verseny tisztaságának és szabadságának érvényesülésével kapcsolatos tapasztalatokról, J/5632 A Gazdasági Versenyhivatal 2007. évi tevékenységéről és a versenytörvény alkalmazása során szerzett, a verseny tisztaságának és szabadságának érvényesülésével kapcsolatos tapasztalatokról; J/2541 A Gazdasági Versenyhivatal 2006. évi tevékenységéről és a versenytörvény alkalmazása során szerzett, a verseny tisztaságának és szabadságának érvényesülésével kapcsolatos tapasztalatokról; J/227 A Gazdasági Versenyhivatal 2005. évi tevékenységéről és a versenytörvény alkalmazása során szerzett, a verseny tisztaságának és szabadságának érvényesülésével kapcsolatos tapasztalatokról,

92 Az Országgyűlés hiteles jegyzőkönyve 2010. évi őszi ülésszak október 11-12-ei ülésének második ülésnapja, 34.szám, point 5166.

93 Jegyzőkönyv az Országgyűlés Gazdasági bizottságának 2016. március 22-én, kedden 9 óra 34 perckor az Országház főemelet 37. számú tanácstermében megtartott üléséről, pp. 5-12. 
This has serious implications for the rule of law institutions and values in Hungary, but it may equally impact the enforcement of EU competition law.

Unlike its network members, the ECN itself cannot be held accountable either to the European Parliament or the national parliaments. It is only its members that are accountable to their respective parliaments, but even in that case not for acts or decisions taken within the ECN, such as case allocation and information exchange. Unlike other EU networks, for example for telecommunications, the ECN is under no obligation to publish annual reports and submit them to the Commission or the European Parliament. Information on and about the work of the ECN is provided through the Commission's annual report and through its website where the ECN publishes a newsletter. ${ }^{94}$

\section{Judicial accountability}

Judicial accountability is not part of the Directive, however, judicial review forms an indispensable part of the enforcement system in order to enhance the quality of administrative actions and to ensure good governance. It is fundamental for economic exchanges, since trade and investment depends on public decision-making bodies being subject to effective means of oversight and legal redress. It is important to address judicial accountability with regard to the Hungarian system and the possible result of the implementation of the Directive. The developments in Hungarian economic policy since 2010 not only comprised of increasing state involvement decision-making mechanisms and often increasing administrative discretion but also restriction or elimination of judicial control of such discretion. In fact, regulatory changes restructuring markets often went hand in hand with limiting the opportunities of individuals for legal redress (The Lendület-HPOPs Research Group, 2017, p. 50). The 2010 suspension of the review powers of the Constitutional Court on matters of fiscal policy certainly represents one of the major examples of this development. ${ }^{95}$ Another example is the exclusion of judicial review against the regulations of the energy regulator following an unfavourable,

\footnotetext{
Jegyzőkönyv az Országgyűlés Gazdasági bizottságának 2016. szeptember 20-án, szerdán 9 óra 04 perckor az Országház főemelet 37. számú tanácstermében megtartott üléséről, pp. 6-23; Jegyzőkönyv az Országgyűlés Gazdasági bizottságának 2018. október 15-én, 11 óra 10 perckor az Országház Tisza Kálmán termében (főemelet 37.) megtartott üléséről.

94 See https://webgate.ec.europa.eu/multisite/ecn-brief/en/brief/editorial, accessed 8 December 2016.

95 It enabled the government to introduce new, controversial fiscal measures and to engage in an equally controversial restructuring of certain economic sectors without being subject to constitutional scrutiny.
} 
for the government, ruling in judicial review by the Budapest Metropolitan Court. ${ }^{96}$

Decisions of the GVH are subject to judicial review at three different levels of the court system. At the two first instances of court review, courts examine the legality of the administrative decisions based on points of law and facts. On third instance, the Supreme Court reviews only on points of law. After those three court instances, the parties may file a constitutional complaint with the Hungarian Constitutional Court. ${ }^{97}$ The standard of review in administrative procedural law is that of 'legality'. ${ }^{98}$ In Hungarian law, judicial review of the legality of administrative decisions covers breaches of both procedural and substantive law, while on the basis of Article 339 it excludes the review of the merits of the administrative decision taken under direct statutory or discretionary powers. The division between the review of legality and the review of merits is, however, not always clear in Hungarian law. ${ }^{99}$

The role of Article 6 of the European Convention on Human Rights (hereinafter: ECHR) on the right to a fair trial in a reasonable time, and the European Court of Human Rights' Menarini judgment ${ }^{100}$, had an important influence in Hungary concerning the standard of judicial review courts should engage in when assessing the GVH's decisions. ${ }^{101}$

96 Varjú showed that it is likely that the new act (Act 2013:XXII) was drafted, in part, as a reaction to the judgment of the Budapest Metropolitan Court allowing the action for judicial review launched by energy companies against regulation of the energy authority amending the network code concerning long-term capacity allocation, therefore, contradicting this particular aspect of the declared government policy on lowering utility prices.

The reduction of legal protection was introduced as part of the general regulatory overhaul of the powers and responsibilities of the regulator and the setting up of the new Hungarian Energy and Public Utilities Regulatory Authority. Under the new rules, the Constitutional Court has jurisdiction to review the regulations issued by the new regulator, but this Court lacks expertise and has often in recent years exercised near complete deference to government discretion in regulating the economy. Hungarian Academy of Sciences, Centre for Social Sciences, Lendület-HPOPs Research Group, The Legal and Regulatory Environment for Economic Activity in Hungary: Market Access And Level Playing-field in the Single Market A legal expert review reportp.2017, Budapest, 50.

97 This procedure exists since the Fundamental Law of Hungary was implemented in 2012.

98 Laid down in Hungarian law by Section 109(1) Administrative Procedure Act, Section 339 of the Code of Civil Procedure.

99 See: Kovács, Varjú, 2014, pp. 195-226. The Hungarian Code on Civil Procedure recognizes two types of questions of fact: simple facts and facts the determination of which requires expert knowledge. Their separation is often controversial, especially in competition law, in which economics-based evidence is used. Often it is unclear whether the public authority has to assess a question of expert evidence or a question of law.

100 ECtHR judgment of 27 September 2011 Menarini Diagnostics SRL v Italy (43509/08).

101 See: Kovács, Varjú, 2014, p. 166. GVH decision Vj-130/2006/239, point 8; Judgment 2Kf.27.360/2006/29; Judgment Kfv.IV.39.399/2007/28. 
Both the Hungarian Constitutional Court and the Hungarian Supreme Court have acknowledged that cartel proceedings are quasi-criminal proceedings which require special guarantees. ${ }^{102}$ In the Railways construction case ${ }^{103}$, the Hungarian Supreme Court concluded that Hungarian courts should be able to fully review the GVH's administrative decisions. In other words, they have the authority to review questions of facts and law; they can modify the GVH's decision with their own, for example, to reduce the fines imposed by the GVH. ${ }^{104}$ In the Supreme Court's view, the courts should consider the GVH's decision as an indictment in penal law and during judicial review the plaintiffs can prove that a more reasonable assessment of the evidence exists (Papp, 2017, p. 265; Tóth, 2018). Moreover, according to the Supreme Court, full judicial review can lead to setting aside the rule that precludes courts from reconsidering decisions of administrative authorities taken in the course of their discretionary powers. ${ }^{105}$

While more recent judgments of the Supreme Court have somewhat limited this full review approach based on the ECHR, in the Early repayment home loan case, the Supreme Court was clear that administrative procedures, thus the GVH's procedures, must meet the requirements laid down in Article 6 ECHR and, as such, they need to take account of the fact to what extent the administrative procedure lives up to the standard of fair and judicial procedure. ${ }^{106}$ The Supreme Court has extensively analyzed how the GVH's procedures comply with the principles of equality of arms and the principle of adversarial procedure. ${ }^{107}$

In this respect, the Supreme Court has assessed how the GVH's structure, and especially the position of the Competition Council as its decision-making body, and procedures comply with these principles. It came to the conclusion that the procedures of the GVH and the way investigation is conducted by case-handlers and reported to the decision-making body, the Competition Council, do not comply with the principle of adversarial procedure. ${ }^{108}$

102 Constitutional Court decision no. 30/2014 and Supreme Court judgment no. Kfv. III.37.690/2013/29.

103 Judgment Kfv.III.37.690/2013/29.

104 Kfv.III.37.690/2013/29, 30-31.

105 This rule is laid down in Article 339 of the Hungarian Civil Procedural Code. Article 339/B of the Procedural Code sets a limit on the competence of the courts to review administrative decisions based on discretion; in practice, in reviewing the fines, the courts have the competence to overrule de facto the discretion exercised by the $\mathrm{GVH}$ with the reasoning that the facts established by the court are in contradiction with the records.

106 Kfv.III.37.582/2016/16. Para 121-122.

107 Kfv.III.37.582/2016/16. Para 121-122.

108 The CC does not act like a judicial forum, listening to the arguments of both parties and then deciding their legal dispute based upon the facts and legal arguments presented. The CC 
Therefore, the GVH procedure does not meet all the requirements of Article 6 ECHR and, as such, the Supreme Court stated that the judicial review process should ensure that the legal protection envisaged under the ECHR exists. Consequently, administrative courts must be able to consider the full range of relevant facts and legal issues and review the decision of the GVH in a sufficiently rigorous manner considering the legality and the rationality of the decision as well as whether procedural rules were complied with. ${ }^{109}$ This approach has been confirmed by the Constitutional Court in another case ${ }^{110}$ where it stated that the standard of proof in administrative cases should effectively be the same as under criminal law.

It has been argued that in practice, courts first seemed to be passive in their review judgments, perhaps because of the specific rule limiting their review of GVH's decisions in its discretionary powers (Tóth (2018) p. 53). However, today they are more actively assessing and turning over GVH's decisions, which may be a consequence of the Supreme and Constitutional Court's interpretation of the standard of review. ${ }^{111}$

Despite the more rigorous judicial review by Hungarian courts, the effectiveness of the justice system increasingly raises concerns, in particular as regards judicial independence. Over the last year, perceived judicial independence among businesses decreased in Hungary ${ }^{112}$ and checks and balances within the ordinary courts system further weaken. In December 2018, the Hungarian Parliament proposed two legislative acts establishing an administrative courts system. The new law would create a self-standing branch of administrative courts, technically within the Hungarian judiciary, yet, placed under the direction of a separate, newly established Supreme Administrative Court, alongside the existing Supreme Court (Uitz, 2019). Even though the Hungarian government has postponed the creation of these special administrative courts, independence of the judiciary remains a concern in Hungary as shown by recent preliminary questions asked by Hungarian judges (Kochenov, Bárd, 2019; Bárd, 2019).

\footnotetext{
is part of the $\mathrm{GVH}$, and is involved to some extent in the case handlers' investigation, as far as it can give advice about the directions of the investigation. See: Tóth, 2018, p. 50.

109 Kfv.III.37.582/2016/16. Paras 126-128.

110 Decision of the Constitutional Court No. 30/2014 (IX. 30.). The Constitutional Court acted upon the complaint of an undertaking who challenged the Curia's final judgment (Kfv. II.37.076/2012/28.)

111 Nagy argued that it may also be a consequence of more demanding effects analysis centering around actual effects [Vj- 96/2010/394 (Contact lenses), Kfv.11.37.110/2017/13 (Supreme Court); Vj- 8/2012/1751 (Bank Data)]. See: Nagy, 2018.

1122019 EU Justice Scoreboard, https://ec.europa.eu/info/sites/info/files/justice_scoreboard_2 019 en.pdf.
} 


\section{Conclusions}

This paper voices three main points of criticism concerning the Directive that has the aim to make national competition authorities more effective enforcers of competition law. First, the paper analyzed how the multi-level enforcement system that was created by decentralization and Regulation 1/2003 posed challenges to the uniform and consistent application of Articles 101 and 102 TFEU. Five years into the implementation of Regulation 1/2003, the Commission has already started to drive for more harmonization. While Member States voluntarily also converged their procedural framework to that of the Commission's procedures, it has been the work within the ECN, and with the dominant guiding role of the Commission, that convergence has been encouraged. While convergence has so far been documented and encouraged through soft law documents within the framework of the ECN, the Directive is now hard law that necessitates convergence. This, however, does not mean that such guided convergence will in fact result in more effective enforcement. Second, and related to the previous issue, as the case of Hungary shows there may be a limited number of changes necessary in national law to implement the Directive. However, there is a real risk that the Directive, and the particular provisions on institutional capacity (independence and accountability), will be implemented and fully complied with in national law without producing any significant impact on more effective enforcement. Hungary's example shows that institutions interact and influence law enforcement in a very subtle ways. In a country where the overall institutional capacity of administrative authorities has been deteriorating for the past years, where the competition authority has been several times constrained directly by the government in its enforcement work or by legislation to conduct proper competition law investigations and where political accountability is disappearing, a future implementation in black letter law will be meaningless and just function as a cover up for the underlying institutional shortcomings. Even though the Directive does not elaborate on the role of national courts, their review is vital both to guarantee judicial accountability of the NCAs and to truly make NCAs more effective enforcers of competition law. 


\section{Literature}

Bache I., Jordan A. (2006). Europeanization and Domestic Change in Bache I., Jordan A., (eds.), The Europeanization of British Politics, Palgrave Macmillan.

Bárd P. (2019). "Am I Independent?” - A Hungarian Judge Asks the CJEU in a Struggle against Judicial Capture, September 2019, Reconnect. https://reconnect-europe.eu/blog/ politics-newep-krum-2.

Barkow R.E. (2010). Insulating Agencies: Avoiding Capture Through Institutional Design. Texas Law Review, 89, 15.

Bassola B., Kékuti Á., Marosi Z. (2011). Versenyjogi vádalku? - A kötelezettségvállalás intézménye kritikus szemmel, Magyar Jog, 58(12).

Cengiz F. (2009). Regulation 1/2003 Revisited, 42 TILEC Discussion Paper.

Crane, D.A. (2011). The Institutional Structure of Antitrust Enforcement, Oxford University Press.

Csépai B. (2015). The Ceasefire Is over, European Competition Law Review 36, no. 9.

Cseres, K.J. (2013). Integrate or Separate - Institutional Design for the Enforcement of Competition Law and Consumer Law, Amsterdam Law School Research Paper No. 2013-03; Amsterdam Centre for European Law and Governance Research Paper No. 2013-01.

Cseres K.J. (2014). Accession to the EU's competition law regime: a law and governance approach. Yearbook of Antitrust and Regulatory Studies, 7(9).

Cseres K.J. (2015). Competition Law Enforcement Beyond the Nation-State: A Model for Transnational Enforcement Mechanisms? in H-W Micklitz and A Wechsel (eds.), The Transformation of Enforcement, Hart.

Cseres K.J., Outhuisje, A. (2017 A). Parallel enforcement and accountability: the case of EU competition law, in: M. Scholten and M. Luchtman (eds.), Law Enforcement by EU Authorities. Political and judicial accountability in a shared legal order, Edward Elgar, Cheltenham.

Cseres, K.J. (2017 B). Rule of Law Values in the Decentralized Public Enforcement of EU Competition Law. In A. Jakab, D. Kochenov (Eds.), The Enforcement of EU Law and Values: Ensuring Member States' compliance, OUP.

ECN Working Group Cooperation Issues and Due Process, Decision-Making Powers Report, 31 October 2012; http://ec.europa.eu/competition/ecn/decision_making_ powers_report_en.pdf.

Fox E.M. (2010). Antitrust and Institutions: Design and Change, Loyola University Chicago Law Journal, 41.

Fox, E.M., Trebilcock, M.J. (2012). The Design of Competition Law Institutions and the Global Convergence of Process Norms: The GAL Competition Project, NYU Law and Economics Research Paper No. 12-20.

Gauer C. (2001). Does the Effectiveness of the EU Network of Competition Authorities Require a Certain Degree of Harmonisation of National Procedures and Sanctions?' in C.D. Ehlermann, I. Atanasiu (eds.), European Competition Law Annual 2000: The Modernisation of EC Antitrust Policy, Oxford.

Gerber D.J. (1998). Law and Competition in Twentieth Century Europe: Protecting Prometheus, Clarendon Press.

Gerber D.J. (2008). Competition Law and the Institutional Embeddedness of Economics, in J. Drexl (ed.) Economic Theory and Competition Law. Available at SSRN: http://ssrn. com/abstract $=1306482$. 
Guidi M. (2011). Does independence affect regulatory performance? The case of national competition authorities in the European Union, European University Institute Working Papers, 64.

Guidi M. (2014). Delegation and varieties of capitalism: Explaining the independence of national competition agencies in the European Union, Comparative European Politics, 12.

Hanretty C., Larouche P., Reindl A. (2012). Independence, Accountability and Perceived Quality of Regulators, CERRE Report, https://www.cerre.eu/sites/cerre/files/120306_ IndependenceAccountabilityPerceivedQualityofNRAs.pdf.

Hyman D.A., Kovacic W.E. (2012). Government Organization/Reorganization: Why Who Does What Matters, Illinois Program in Law, Behavior and Social Science Paper No. LE 12-14; GWU Legal Studies Research Paper No. 2012-70.

Iancu B., Tănăsescu S.E. (eds.) (2019). Governance and Constitutionalism Law, Politics and Institutional Neutrality, Routledge.

Jenny F. (2000). Does the Effectiveness of the EU Network of Competition Authorities Depend on a Certain Degree of Homogeneity within its Membership?' in CD Ehlermann, I Atanasiu (eds.), European Competition Law Annual.

Kapural M. (2014). New kid on the block-Croatia's path to convergence with EU competition rules, Journal of Competition Law \& Practice 5(4).

Knill C., Lenschow A. (1998). Coping with Europe: the impact of British and German administrations on the implementation of EU environmental policy, Journal of European Public Policy, 5.

Kochenov D., Bárd P. (2019). The Last Soldier Standing? Courts vs. Politicians and the Rule of Law Crisis in the New Member States of the EU, University of Groningen Faculty of Law Research Paper No. 5/2019. Available at SSRN: https://ssrn.com/abstract= 3339631.

Kovács A., Varjú M. (2014). Hungary: The Europeanization of Judicial Review, European Public Law, Vol. 20, Issue 2.

Láncos P. (2019). The Power of Soft Law: Spontaneous Approximation of Fining Policies for Anti-competitive Conduct, unpublished manuscript.

Landis James M. (1938). The Administrative Process, Yale University Press.

Mattei U., Antoniolli L., Rossato A., Comparative Law and Economics (2000) [in:] B. Bouckaert, G. De Geest (eds.), Encyclopedia of Law and Economics, Cheltenham, UK and Brookfield, US.

Monti G. (2014 A). Independence, Interdependence and Legitimacy: the EU Commission, National Competition Authorities, and the European Competition Network, EUI Working Paper Law, 1.

Monti G. (2014 B). Managing decentralized antitrust enforcement: Toshiba', 51 CMLRev 261;

Nagy Cs. (2016 A). Competition law in Hungary, Wolters Kluwer.

Nagy Cs. (2016 B). Administrative Competition Procedure and Judicial Review in Hungary, in Nagy Cs. (eds.) The procedural aspects of the application of competition law, Europa Law Publishing.

Nagy Cs. (2018). Presentation Cs. Nagy at the conference Judicial review, October, 2018, Warsaw, http://www.cars.wz.uw.edu.pl/tresc/konferencje/40/Prezentacja/10_Nagy_ Judicial_review_of_fines_in_Hungary.pdf.

North D. (1990). Institutions, Institutional Change and Economic Performance, Cambridge: Cambridge University Press. 
Ost K. (2014). From Regulation 1 to Regulation 2: National Enforcement of EU Cartel Prohibition and the Need for Further Convergence, Journal of European Competition Law \& Practice, 5(3).

Ottow A. (2015). Market and Competition Authorities: Good Agency Principles, OUP.

Papp M. (2017). Application of EU Competition Law by the Hungarian Judiciary: Cooperation with the ECJ and Relying on the Case Law of the ECtHR in: P.A. Almăşan, P. Whelan (eds.), The Consistent Application of EU Competition Law, Studies in European Economic Law and Regulation, 9.

Petit N. (2014). The Principles of Equivalence and Effectiveness as a Limit to National Procedural Autonomy, Nicolas Petit, ENTraNCE 2014, 5-8 March 2014, available at :https://antitrustlair.files.wordpress.com/2014/07/the-principles-of-equivalence-and-eff ectiveness-n-petit-final.pdf.

Pina A. (2014). Enhancing Competition and the Business Environment in Hungary. OECD Economics Department Working Papers No. 1123, https://www.oecd-ilibrary.org/ economics/enhancing-competition-and-the-business-environment-in-hungary_5jz2pwf r0nzq-en.

Rodrik D., Subramanian A., Trebbi F. (2004). Institutions Rule: The Primacy of Institutions Over Geography and Integration in Economic Development, Journal of Economic Growth, 9(2).

Scholten M., Ottow A. (2014). Institutional Design of Enforcement in the EU: the Case of Financial Markets, Utrecht Law Review 10(5).

Szilágyi G. (2019). Az ECN+ irányelv és várható hatása a magyar versenyszabályozásra, Versenytükör, 1.

The Lendület-HPOPs Research Group (2017). The Legal and Regulatory Environment for Economic Activity in Hungary: Market Access And Level Playing-field in the Single Market A legal expert review report, Hungarian Academy of Sciences, Centre for Social Sciences, Lendület-HPOPs Research Group, Budapest.

Tóth I.J., Hajdu M. (2017). Intensity of Competition, Corruption Risks and Price Distortion in the Hungarian Public Procurement - 2009-2016, Working Paper Series: CRCB-WP/2017:2.

Tóth T. (2013). The Fall of Agricultural Cartel Enforcement in Hungary, Available at SSRN: https://ssrn.com/abstract $=2515967$.

Tóth T. (2018). Life after Menarini: The Conformity of the Hungarian Competition Law Enforcement System with Human Rights Principles, YARS, 11(18).

Treib O. (2006). Implementing and complying with EU governance outputs, Living Reviews in European Governance, 1, www.livingreviews.org/lreg-2006-1.

Uitz R. (2019). An Advanced Course in Court Packing: Hungary's New Law on Administrative Courts, VerfBlog, https://verfassungsblog.de/an-advanced-course-in-court-packing-hunga rys-new-law-on-administrative-courts/, DOI: https://doi.org/10.17176/20190211-223946-0.

Van Cleynenbreugel P.J.M.M. (2012). Institutional assimilation in the wake of EU competition law decentralisation, The Competition Law Review 8(3).

Van Waarden F., Drahos M. (2002). Courts and (epistemic) communities in the convergence of competition policies, Journal of European Public Policy, 9. 